Seasonal dynamics of bi odegradati on act i viti es for di methyl ar si ni c aci d (DNA) in Lake Kahokugat a

\begin{tabular}{|l|l|}
\hline 著者 & $\begin{array}{l}\text { Naki Ter uya, H r ot a Wakana, Ueda Kaor i , } \\
\text { Hasegawa H r oshi , Rahman Mohammad Azi zur }\end{array}$ \\
\hline $\begin{array}{l}\text { j our nal or } \\
\text { publ i cat i on t i t l e }\end{array}$ & Chemospher e \\
\hline vol une & 77 \\
\hline number & 1 \\
\hline page r ange & $36-42$ \\
\hline year & 2009- 09-01 \\
\hline URL & ht t p: //hdl . handl e. net /2297/18645 \\
\hline
\end{tabular}




\title{
Seasonal dynamics of biodegradation activities for dimethylarsinic acid (DMA) in Lake Kahokugata
}

\author{
Teruya Maki*, Wakana Hirota, Kaori Ueda, Hiroshi Hasegawa, Mohammad Azizur Rahman \\ Graduate School of Natural Science and Technology, Kanazawa University, Kakuma-machi, Kanazawa-shi 9201192, Japan
}

\section{Article history:}

Received 30 January 2009

Received in revised form 30 May 2009

Accepted 2 June 2009

Available online $\mathrm{xxxx}$

\section{Keywords:}

Biodegradation

Speciation

Chemical limnology

Organoarsenic

\begin{abstract}
A B S T R A C T
The microbial activities in aquatic environments significantly influence arsenic cycles such as the turnover between inorganic arsenic and organoarsenic compounds. In Lake Kahokugata, inorganic arsenic was detected at concentrations ranging from 2.8 to $23 \mathrm{nM}$ in all seasons, while the concentrations of dimethylarsinic acid (DMA) produced by microorganisms such as phytoplankton changed seasonally and showed a peak in winter. The changes in the concentrations of methylarsenic species did not correlate with the changes in phytoplankton abundance (chlorophyll $a$ contents), suggesting that DMA-degradation is related to this inconsistency. DMA $(1 \mu \mathrm{M})$ added into the lake water was converted to inorganic arsenic at $20^{\circ} \mathrm{C}$ only under anaerobic and dark conditions, while DMA degradation was diminished under aerobic or light conditions. Moreover, DMA added to the lake water samples collected through four seasons was degraded at the same rates under anaerobic and dark conditions at $20^{\circ} \mathrm{C}$. However, at $30^{\circ} \mathrm{C}$, $1 \mu \mathrm{M}$ of DMA in the summer lake water samples was rapidly degraded in 7 and $21 \mathrm{~d}$. In contrast, DMA degradation was diminished in the winter lake water samples at $4{ }^{\circ} \mathrm{C}$ of incubation. Presumably, DMAbiodegradation activities are mainly controlled by changes in the water temperature in Lake Kahokugata, where the arsenic concentrations change seasonally.
\end{abstract}

() 2009 Published by Elsevier Ltd.

\section{Introduction}

Arsenic compounds are widely distributed in aquatic environments in a variety of chemical forms, and some of them are known to endanger human health and organism activities at high concentrations (Cullen and Reimer, 1989; Ninh et al., 2008; Peshut et al., 2008). The dynamics of arsenic forms have attracted much attention from those seeking to understand the arsenic cycles in aquatic environments (Oremland and Stolz, 2003). Among the variety of arsenic species, arsenate, arsenite, and methylated arsenic compounds dominate in both fresh water and seawater environments, and the conversion process mainly depends on the bioactivities of microorganisms that readily metabolize the arsenic species (Oremland and Stolz, 2003). The microbial reduction of arsenate in soils enhanced the release of arsenic compounds into ground water, causing the arsenic contamination of drinking water (Stolz et al., 2006). Microorganisms, such as phytoplankton (microalgae) and bacteria, uptake and accumulate ambient arsenate under phosphate-limited conditions through their phosphate-metabolism because arsenate is a chemical analogue of phosphate (Andreae, 1979; Farías et al., 2007). Moreover, the phytoplankton in aquatic environments reduce arsenate into arsenite or methylate it into

\footnotetext{
* Corresponding author. Tel.: +81 (0)76 234 4793; fax: +81 (0)76 2344800

E-mail address: makiteru@t.kanazawa-u.ac.jp (T. Maki).
}

monomethylarsonic acid $\left(\mathrm{CH}_{3} \mathrm{AsO}(\mathrm{OH})_{2} ; \mathrm{MMA}(\mathrm{V})\right)$ and dimethylarsinic acid $\left(\left(\mathrm{CH}_{3}\right)_{2} \mathrm{AsO}(\mathrm{OH})\right.$; DMA(V)) (Francesconi and Kuehnelt, 2002). The produced MMA and DMA are subsequently converted to more complex organoarsenic compounds such as tetramethylarsonium ion and arsenosugars by phytoplankton, bacteria, and/ or fungi (Francesconi and Kuehnelt, 2002).

Although phytoplankton produce organoarsenic compounds in aquatic environments, there was not a significant positive correlation between the in situ amounts of chlorophyll $a$ (the biomass of phytoplankton) and of organoarsenic compounds in aquatic environments (Hasegawa, 1996). Sohrin et al. (1997) speculated that environmental degradation of organoarsenic compounds by bacteria had led to this inconsistency. The dominant chemical forms in a number of lakes and estuaries have been reported to change seasonally by the degradation and production of organoarsenic compounds (Anderson and Bruland, 1991). Considering the seasonal dynamics and the distribution of arsenic compounds in aquatic environments, the DMA-degradation process is worthy of study. A few reports described that environmental bacteria in marine sediments (Sanders, 1979), seawater (Kaise et al., 1985), and associated consorcia with marine animals, such as crabs (Khokiattiwong et al., 2001) and mussels (Jenkins et al., 2003), could degrade the organoarsenic compounds amended. Bacterial isolates from activated sludge (Quinn and McMullan, 1995) and natural environments (Lehr et al., 2003; Maki et al., 2006a,b) also 
degraded organoarsenic compounds to inorganic arsenic. However, little information is available on the influence of environmental factors on the DMA-biodegradation process in aquatic environments, and the ecological characteristics of DMA biodegradation are unclear. In our previous investigation, the bacterial composition of DMA-degrading bacteria was demonstrated to change seasonally in the lakes of Japan (Maki et al., 2006a,b), but, until the present study, the seasonal dynamics of biodegradation activities for organoarsenic compounds had not been estimated in detail in a single lake.

In this study, the seasonal change in the concentrations of arsenic species was investigated in Lake Kahokugata from April 2005 to March 2008 to estimate the interaction of the arsenic dynamics between arsenic compounds and chlorophyll a. Moreover, environmental factors controlling DMA degradation were determined in the lake water samples spiked with DMA, and the DMA-degradation activities in the natural lake water were estimated in all seasons during the investigation period. DMA was selected as a representative organoarsenic compound that is widely distributed in freshwater (Sohrin et al., 1997).

\section{Experimental}

\subsection{Sampling at Lake Kahokugata}

A lake water sample at a depth of $1 \mathrm{~m}$ was collected in polycarbonate bottles from Lake Kahokugata in the Ishikawa Prefecture of Japan 22 times from April 2005 to March 2008. Lake Kahokugata is eutrophic and suffered from wastewater inflow from cities and croplands. The depth of Lake Kahokugata is less than $2 \mathrm{~m}$ and the water is frequently mixed throughout the four seasons. The oxygen levels in the lake water sample ranged from 2.0 to $8.3 \mathrm{mg} \mathrm{L}^{-1}$ during the investigation period. When the water transparency was measured using a standard $25 \mathrm{~cm}$ black and white Secchi disk, the disk depths ranged from $0.1 \mathrm{~m}$ to $1 \mathrm{~m}$ from water surface during the investigation period, indicating that the sun irradiation hardly reached to the depth of $1 \mathrm{~m}$. For the measurement of arsenic species and chlorophyll $a, 50 \mathrm{~mL}$ of sample water was filtrated with a GF/C glass fiber filter (ADVANTEC, Tokyo, Japan). The concentrations of arsenic species in the filtrate were determined using a cold trap HG-AA speciation procedure. Chlorophyll $a$ was extracted from the GF/C glass fiber filter with acetone and assessed colorimeterically (Maki et al., 2005). Moreover, surface water samples of Lake Kahokugata in several polycarbonate bottles were used for the determination of the DMA-biodegradation activities of natural lake water. These samples were incubated under different treatments.

\subsection{Experiment design and DMA biodegradation in lake water}

The lake water samples collected into polycarbonate bottles from Lake Kahokugata on October 10, 2006, were used for investigating DMA-degradation activities in lake water samples incubated under aerobic and anaerobic conditions and light and dark conditions. Twelve polycarbonate bottles $(500 \mathrm{~mL})$ were filled up with lake water and transferred to our laboratory. Within $2 \mathrm{~h}$ of sampling, $500 \mu \mathrm{L}$ of a $1 \mathrm{mM}$ DMA (Nacalai Tesque, Kyoto, Japan) solution was added into 12 bottles at a final concentration of $1 \mu \mathrm{M}$. One half of the bottles (six) in each experiment were incubated under anaerobic conditions. To produce the anaerobic conditions, the air phases in the bottles were kept at the lowest possible level, and the water samples were purged with nitrogen $\left(100 \mathrm{~mL} \mathrm{~min}^{-1}\right)$ for $0.5 \mathrm{~h}$. The remaining half of (six bottles) were incubated under aerobic conditions. To produce the aerobic conditions, natural air filtrated through a $0.2 \mu \mathrm{m}$ Nuclepore filter (Whatman, Tokyo, Ja- pan) was continuously supplied at $700 \mathrm{~m}^{3} \mathrm{~h}^{-1}$ into the bottle using an air-pump. After the anaerobic and aerobic treatments, three bottles under each anaerobic and aerobic condition were incubated under a photon flux density of $150 \mu \mathrm{mol} \mathrm{m}^{-2} \mathrm{~S}^{-1}$ of cool white fluorescent lamps with a 12:12 light:dark cycle as the light condition. The remaining three bottles under each anaerobic and aerobic condition were incubated under dark conditions by covering the bottles with aluminum foil. The experiments consisted of a total of four conditions: anaerobic and light, aerobic and light, anaerobic and dark, and aerobic and dark. The water samples were then incubated in a controlled temperature room $\left(20^{\circ} \mathrm{C}\right)$. Moreover, for estimating the biosynthesis from arsenate to DMA, arsenate was added to $500 \mathrm{~mL}$ bottles of lake water samples at a final concentration of $1 \mu \mathrm{M}$, and a single bottle of the water samples was incubated at $20^{\circ} \mathrm{C}$ under each of four conditions.

On the other hand, the microbial activities in the lake water sample were eliminated using four treatments: the lake water was autoclaved at $120^{\circ} \mathrm{C}$ for $20 \mathrm{~min}$; an antibiotic mixture was added to each sample of lake water at a final concentration of $10 \mathrm{mg} \mathrm{L}^{-1}$; sodium azide was added to each sample of lake water at a final concentration of $10 \mathrm{mg} \mathrm{L}^{-1}$; and the lake water was filtrated through a $0.02 \mu \mathrm{m}$ polycarbonate filter. Three bottles $(500 \mathrm{~mL})$ of the lake water samples treated by each method and spiked with DMA at a final concentration of $1 \mu \mathrm{M}$ were incubated at $20^{\circ} \mathrm{C}$ under anaerobic and dark conditions. The oxygen concentrations of the lake water sample under the aerobic condition were always approximately $8.5 \mathrm{mg} \mathrm{L}^{-1}$. In the anaerobic condition, the oxygen levels ranged from 1.2 to $2.3 \mathrm{mg} \mathrm{L}^{-1}$ during the experiments.

In order to compare the DMA-degradation activities in the lake water in four seasons, spring (March, April, and May), summer (June, July, and August), fall (September, October, and November), and winter (December, January, and February), lake water samples were collected every few months from June 2005 to February 2008 in polycarbonate bottles $(500 \mathrm{~mL}$ ). The $500 \mu \mathrm{L}$ of $1 \mathrm{mM}$ DMA solution was added into bottles at a final concentration of $1 \mu \mathrm{M}$, and the bottles were incubated at $20^{\circ} \mathrm{C}$ under anaerobic and dark conditions. Furthermore, to examine the effects of water temperature on the DMA-degradation activities, the lake water samples that were collected in summer (July 1, 2006, July 28, 2006, and August 9,2007 ) and winter (December 13, 2006, February 28, 2007, and February 3, 2008) and spiked with DMA added at a final concentration of $1 \mu \mathrm{M}$ were incubated under anaerobic and dark conditions at temperatures of $30^{\circ} \mathrm{C}$ and $4{ }^{\circ} \mathrm{C}$, respectively, in controlled-temperature boxes for $56 \mathrm{~d}$. Each experiment was performed in triplicate. water samples were collected, and the concentrations of arsenic species were determined using a cold-trap hydride-generation atomic-absorption (HG-AA) speciation procedure.

\subsection{Measurements of the arsenic compound concentration}

The cold-trap HG-AA speciation procedure was employed as the protocol previously reported (Braman and Foreback, 1973; Hasegawa et al., 1994). The water subsamples, which were filtrated through a $0.45 \mu \mathrm{m}$ cellulose ester filter (ADVANTEC, Tokyo, Japan), were adjusted to $40 \mathrm{~mL}$ using pure water and acidified by the addition of $5 \mathrm{~mL}$ of a $0.2 \mathrm{M}$ EDTA solution and $5 \mathrm{~mL}$ of $5 \mathrm{M} \mathrm{HCl}$. Next, $10 \mathrm{~mL}$ of a $30 \%\left(\mathrm{w} \mathrm{v}^{-1}\right) \mathrm{NaBH}_{4}$ solution was gradually added to the sample solution at a speed of $2 \mathrm{~mL} \mathrm{~min}^{-1}$, and the arsenic included in the sample solution was evaporated by reacting with $\mathrm{NaBH}_{4}$. The produced arsines were swept by a flow of nitrogen into a cold-trap column cooled by liquid nitrogen. After the column was gently warmed by electrical heating, the arsines (including inorganic arsenic, MMA, and DMA) released from the column were
During the incubation period $(56 \mathrm{~d})$, portions $(10 \mathrm{~mL})$ of the 
loaded into a quartz-T tube held at about $900{ }^{\circ} \mathrm{C}$ in a flame and quantified using an atomic absorption spectrometer Z-8100 (Hitachi, Chiba, Japan). The potential concentrations for detection of arsenic compounds were more than $1.0 \mathrm{nM}$ of measured solution. Moreover, there is a low possibility that other arsenic species, except for inorganic arsenic, MMA, and DMA, are produced in the water samples during the experiments.

\section{Results}

\subsection{Seasonal variation in Lake Kahokugata}

In Lake Kahokugata, the concentrations of chlorophyll $a$ increased to amounts in excess of $50 \mu \mathrm{g} \mathrm{L}^{-1}$ from spring to summer and decreased to below $15 \mu \mathrm{g} \mathrm{L}{ }^{-1}$ from fall to winter during the investigation period between April 2005 and March 2008, suggesting that the growth of phytoplankton was activated from spring to summer (Fig. 1a). The concentrations of inorganic arsenic fluctuated ranging from 2.8 to $23 \mathrm{nM}$ through all seasons, while DMA was detected at peaks of up to $13 \mathrm{nM}$ only during fall and winter. Moreover, MMA was not detected from water samples during the investigation period. Consequently, the changes in the concentrations of methylarsenic compounds did not correlate with the changes in phytoplankton abundance during the investigation period. Furthermore, the water temperature was below $10^{\circ} \mathrm{C}$ during winter and early spring (from December to April), while it increased to over $30^{\circ} \mathrm{C}$ in summer (August) (Fig. 1b).

\subsection{Incubation condition of DMA biodegradation in the lake water from Lake Kahokugata}

When the lake water samples were spiked with DMA at a final concentration of approximately $1 \mu \mathrm{M}$ and incubated at $20^{\circ} \mathrm{C}$ under anaerobic and dark conditions, the concentration of DMA at the onset of the experiment decreased from $1020 \mathrm{nM}$ (average) to the detection limit (avg.) during the first $21 \mathrm{~d}$ of incubation (Fig. 2d). In accordance with the decrease of DMA, the concentration of inorganic arsenic, which is considered to be the resultant product from DMA degradation, increased from 5.1 to $850 \mathrm{nM}$ during the first $21 \mathrm{~d}$ and fluctuated over the concentration of $760 \mathrm{nM}$ until $56 \mathrm{~d}$ of incubation. In contrast, under the other three conditions (anaerobic and light, aerobic and dark, and aerobic and light), the reduc-
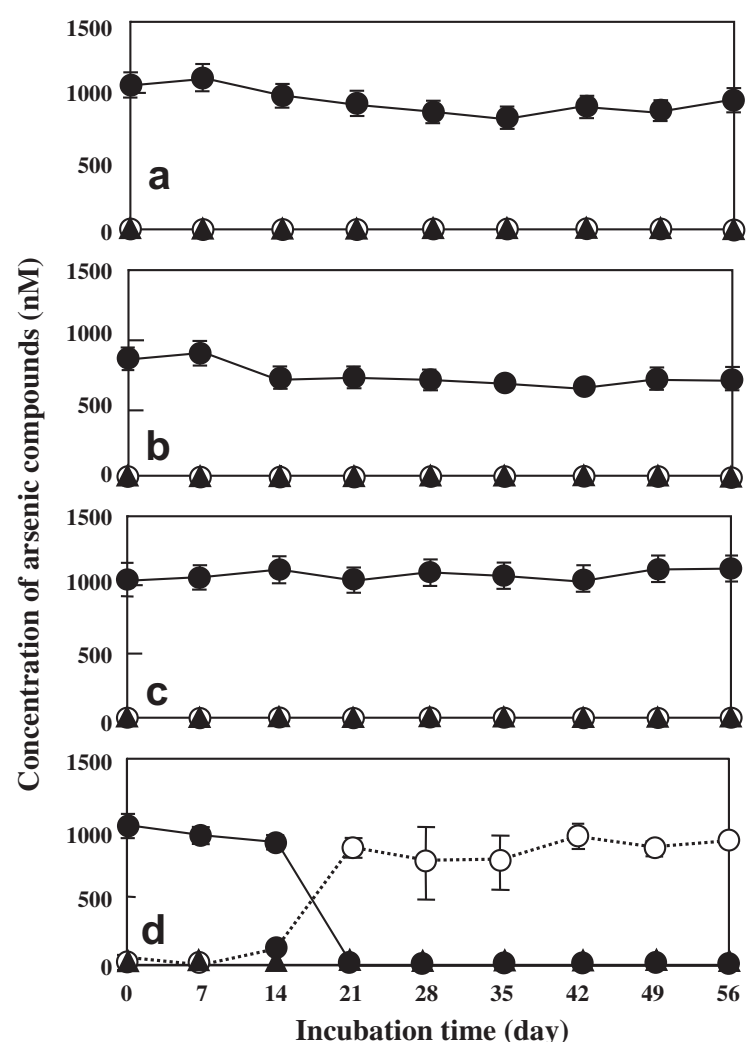

Fig. 2. Changes in the concentrations of arsenic compounds in lake water samples, to which $1 \mu \mathrm{M}$ of DMA was added. The lake water samples were incubated at $20^{\circ} \mathrm{C}$ under aerobic and light conditions (a), aerobic and dark conditions (b), anaerobic and light conditions (c), and anaerobic and dark conditions (d). Open circles, closed circles, and closed triangles indicate the abundance of inorganic arsenic, DMA, and MMA, respectively. Each experiment was performed in triplicate.

tion of DMA and the accumulation of inorganic arsenic were not observed through $56 \mathrm{~d}$ of incubation (Fig. 2a-c). When the microbial activities were eliminated using autoclave sterilization, addition of antibiotics and sodium azide, or filtration, the DMA degradation and the accumulation of inorganic arsenic diminished in the lake water samples with four treatments (Table 1). The concentrations of inorganic arsenic and organoarsenic compounds in

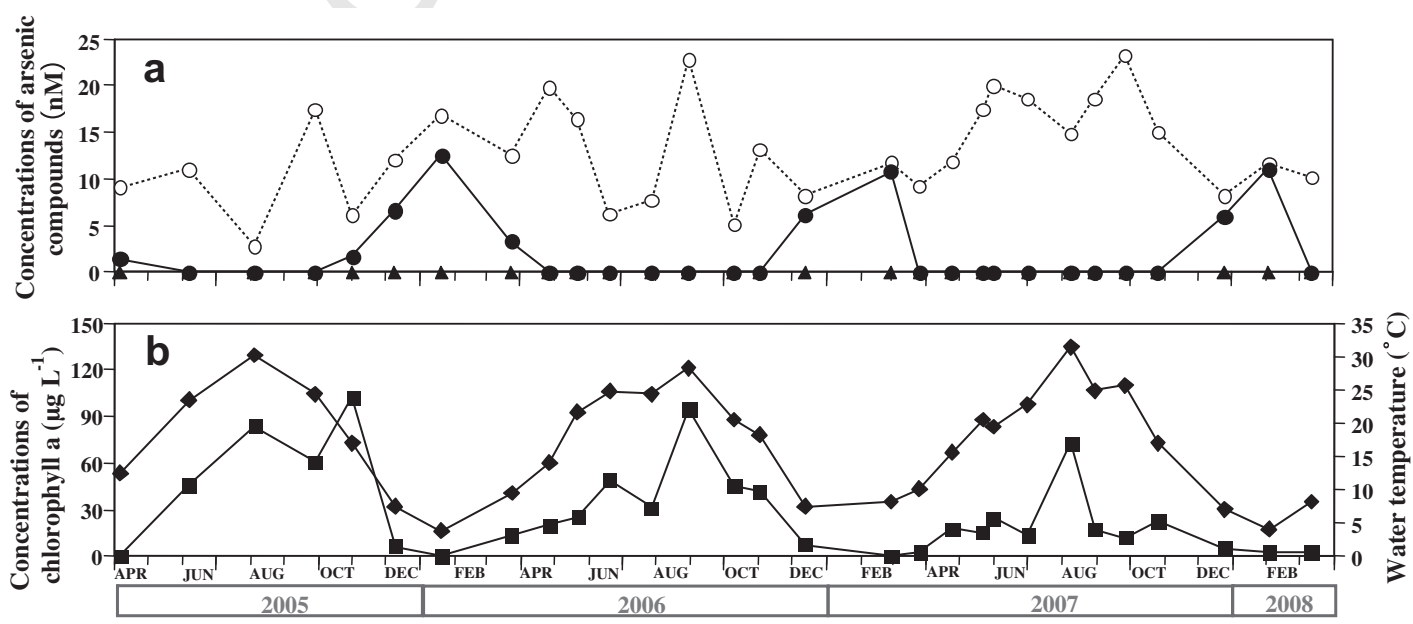

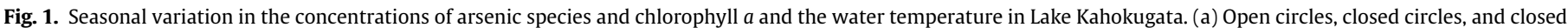

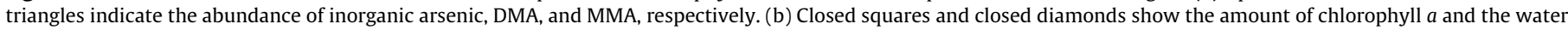
temperature, respectively. 
Table 1

Concentrations of arsenic compounds, such as inorganic arsenic, MMA and DMA, in the lake water of Lake Kahokugata, which were treated for removing microbial activities and spiked with DMA at final concentrations of $938 \pm 63 \mathrm{nM}$. The lake water samples were incubated under the anaerobic and dark condition for $56 \mathrm{~d}$. Each experiment was performed in triplicate.

\begin{tabular}{|c|c|c|c|}
\hline \multirow[t]{2}{*}{ Treatments } & \multicolumn{3}{|c|}{ Concentrations of arsenic species (nM) } \\
\hline & Inorganic arsenic & MMA & DMA \\
\hline Autoclave $^{\mathrm{a}}$ & $<10$ & $<10$ & $971 \pm 71$ \\
\hline Antibiotics addition ${ }^{\mathrm{b}}$ & $<10$ & $<10$ & $837 \pm 43$ \\
\hline $\mathrm{NaN}_{3}$ addition ${ }^{\mathrm{c}}$ & $<10$ & $<10$ & $779 \pm 50$ \\
\hline Filtration $^{\mathrm{d}}$ & $<10$ & $<10$ & $899 \pm 95$ \\
\hline
\end{tabular}

\footnotetext{
a Lake water was autoclaved at $120^{\circ} \mathrm{C}$ for $20 \mathrm{~min}$

b Antibiotics mixture was added to lake water at a each final concentration of $10 \mathrm{mg} \mathrm{L}^{-1}$

c $\mathrm{NaN}_{3}$ was added to lake water at a final concentration of $10 \mathrm{mg} \mathrm{L}^{-1}$.

d Lake water was filtrated with $0.02 \mu \mathrm{m}$ polycarbonatefilter.
}

the lake water without the addition of DMA, on the other hand, were stable below $10 \mathrm{nM}$ during the entire experiment (data not shown). These results indicated that this DMA degradation occurred as a result of a biotic (microbiological) process under anaerobic and dark conditions and that the physical degradation, including photochemical degradation and heat degradation, could be ignored. On the other hand, in the lake water that was spiked with inorganic arsenic, the concentrations of DMA maintained low concentrations ranged below $450 \mathrm{nM}$ from the 14 th day to the 56th day (Fig. 3). These results indicated that the rates of DMA synthesis are at relatively low levels, in contrast to those of DMA degradation.
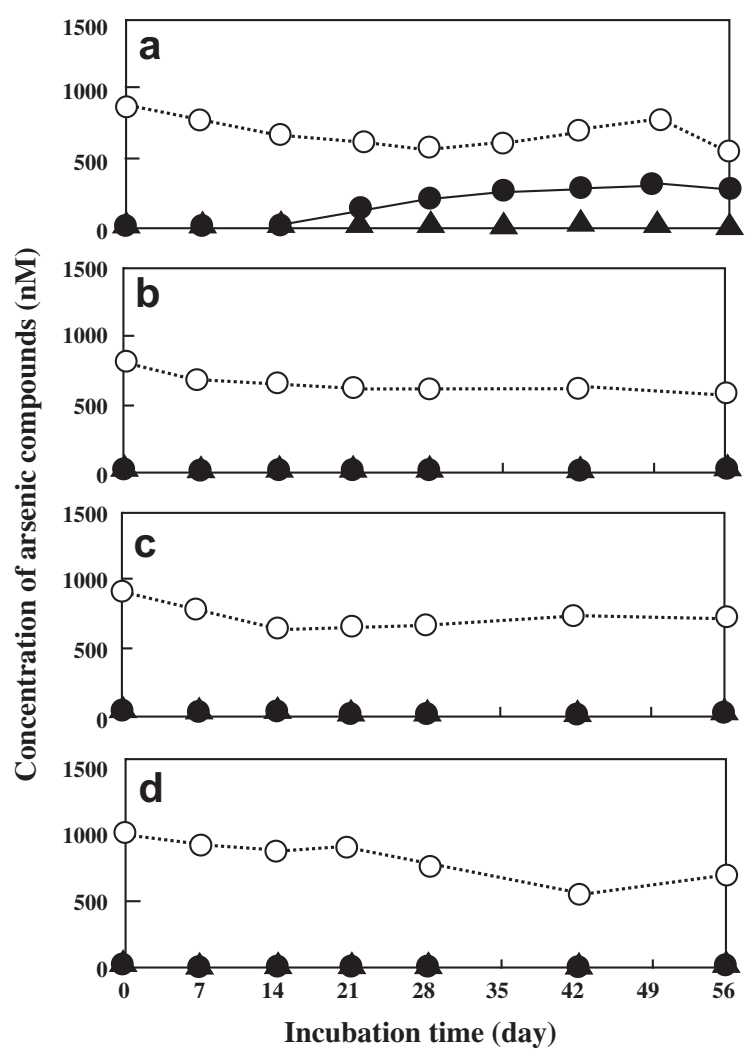

Fig. 3. Changes in the concentrations of arsenic compounds in lake water samples to which $1 \mu \mathrm{M}$ of inorganic arsenic have been added. The lake water samples were incubated at $20^{\circ} \mathrm{C}$ under aerobic and light condition (a), aerobic and dark condition (b), anaerobic and light condition (c), and anaerobic and dark condition (d). Open circles, closed circles, and closed triangles indicate the abundance of inorganic arsenic, DMA, and MMA, respectively.
3.3. Seasonal dynamics of DMA-biodegradation activities in the lake water

In the lake water samples that were collected in four seasons and incubated with the addition of approximately $1 \mu \mathrm{M}$ DMA at $20{ }^{\circ} \mathrm{C}$ under anaerobic and dark conditions, the DMA added to most of the lake water samples collected in the four seasons ( 15 samples of 22) decreased to the detection limit and was completely converted to inorganic arsenic between 21st day and 28th day of incubation (Fig. 4). In the other seven samples of lake water collected in spring, summer, and fall (sampling days -7 June 2005, 1 November 2005, 27 April 2006, 1 September 2006, 24 April 2007, 9 August 2007, and 26 October 2007), the DMA biodegradation and the accumulation of inorganic arsenic were observed for longer incubation times ranging from 35 to $56 \mathrm{~d}$. Consequently, at $20{ }^{\circ} \mathrm{C}$ of incubation under anaerobic and dark conditions, DMA added to the lake water samples was degraded at similar rates throughout the four seasons.

\subsection{DMA-degradation activities of lake water samples at different temperatures}

The degradation patterns of DMA were significantly different at different incubation temperatures, such as $30^{\circ} \mathrm{C}$ and $4{ }^{\circ} \mathrm{C}$, under anaerobic and dark conditions using lake water collected in the summer (July and August) and winter (February and March), respectively. In the lake water collected in the summer and incubated at $30^{\circ} \mathrm{C}, 1 \mu \mathrm{M}$ of DMA was rapidly degraded and converted to $860 \mathrm{nM}$ of inorganic arsenic for short incubation times ranging from $7 \mathrm{~d}$ to $21 \mathrm{~d}$ (Fig. 5a). In contrast, DMA degradation was not observed in the winter lake water samples, which was incubated at $4{ }^{\circ} \mathrm{C}$ (Fig. 5b). At $20^{\circ} \mathrm{C}$, DMA spiked into the same water samples of summer and winter was completely degraded in 21 or $35 \mathrm{~d}$ (Fig. 4b and d). These results mean that DMA degradation was activated at a high temperature of $30^{\circ} \mathrm{C}$ and reduced at a low temperature of $4{ }^{\circ} \mathrm{C}$.

\section{Discussion}

Phytoplankton in lake water and coastal seawater incorporate and accumulate inorganic arsenics instead of phosphorus and synthesize organoarsenic compounds for detoxification (Andreae, 1979; Santosa et al., 1994; Hasegawa et al., 2001). In Lake Kahokugata, the concentrations of chlorophyll $a$ in water samples indicated peaks (up to $100 \mu \mathrm{g} \mathrm{L}^{-1}$ ) during spring and summer indicating the activity of phytoplankton (Fig. 1). DMA increased to concentrations of up to $13 \mathrm{nM}$ from late fall to winter through the investigation period. These results indicated that the dynamics of methylarsenic species were not related to the dynamics of chlorophyll $a$ in Lake Kahokugata. In lakes and coasted areas, the changes in microalgal abundance (chlorophyll $a$ contents) did not positively correlate with the changes in the concentrations of methylarsenic species (Hasegawa, 1996). In contrast, in other aquatic environments, the concentrations of DMA frequently increased in summer positively and correlated with the production of phytoplankton (Sohrin et al., 1997). Some microorganisms, such as fungi and bacteria, have been reported to produce DMA as well as phytoplankton (Francesconi and Kuehnelt, 2002). Except for phytoplankton, these microorganisms might produce DMA during winter in Lake Kahokugata. Sanders (1979) also demonstrated that microbial communities in environmental freshwater system demethylated DMA to inorganic arsenate. In this study, both the biosynthesis and biodegradation of DMA, which vary with time, seemed to determine the concentration of DMA in aquatic environments. The water samples from Lake Kahokugata spiked with DMA were 


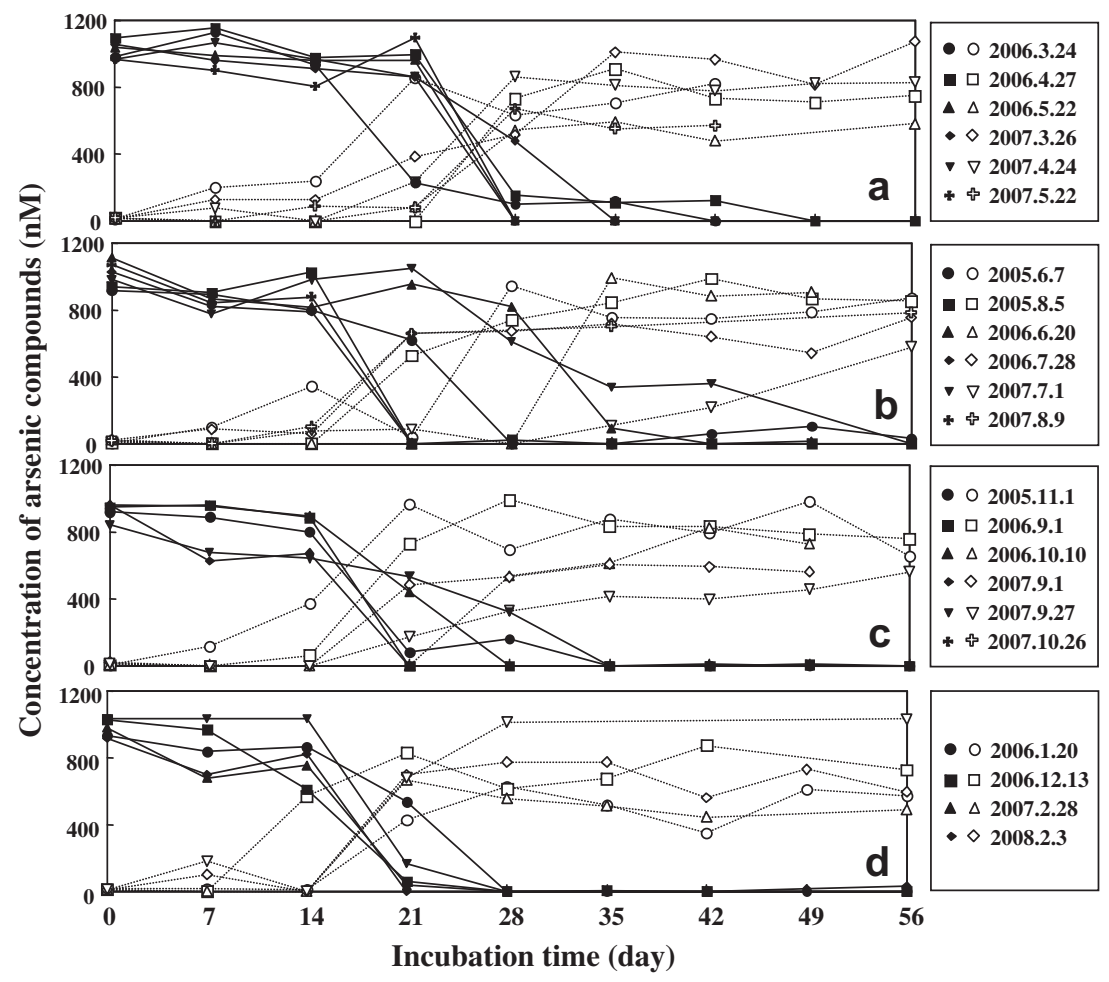

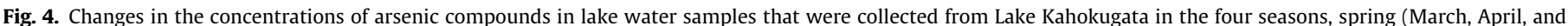

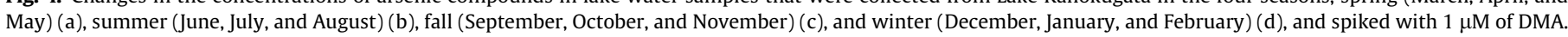

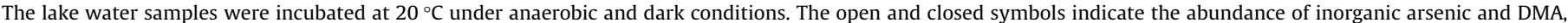
respectively. MMA was below the detection limit.

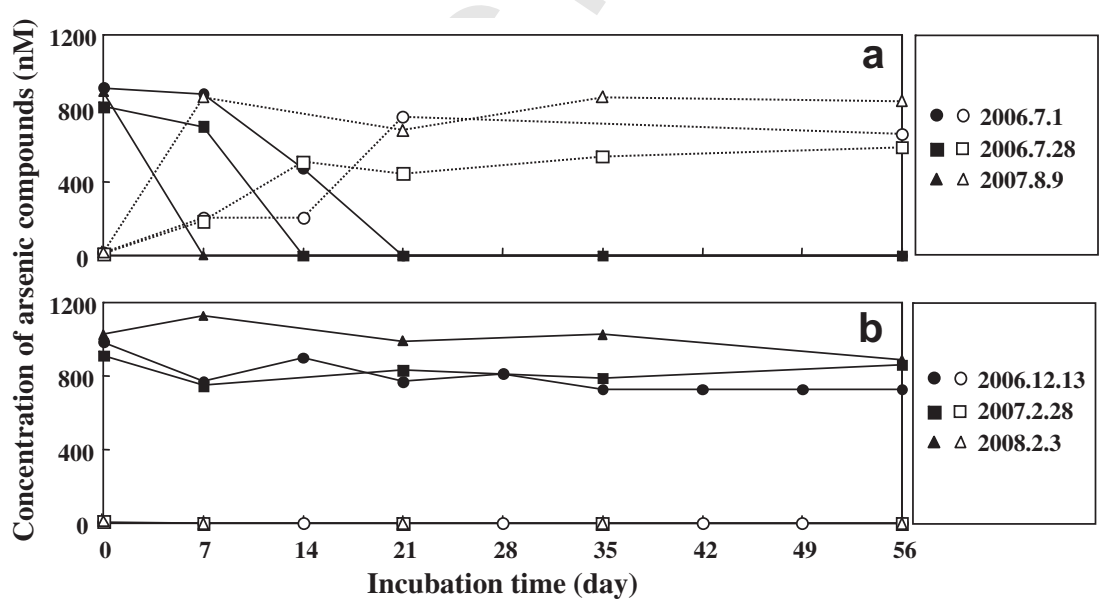

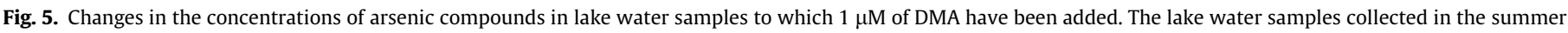

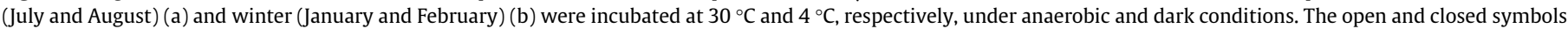
indicate the abundance of inorganic arsenic and DMA, respectively. MMA was below the detection limit.

converted to inorganic arsenic only under dark and anaerobic conditions of incubation (Fig. 2d). Furthermore, this DMA degradation was not observed in the lake water in which the bacterial activities were eliminated by four treatments, including autoclave sterilization, filtration, and the addition of sodium azide and antibiotics. These results suggested that this degradation of DMA occurs as a result of a biotic (microbiological) process. Biological demethylation has been reported to be the dominant process for the generation of inorganic arsenic from organoarsenic compounds (Andreae, 1979). In a previous investigation, several species of DMA-degrading bacteria were isolated from Lake Kahokugata (Maki et al., 2005). This study suggested that the DMA-degrading microorgan- isms generally inhabiting Lake Kahokugata would degrade the methylarsenic compounds produced by microorganisms and influence the arsenic cycling in aquatic ecosystems.

Degradation of DMA to inorganic arsenic occurred only under anaerobic and dark conditions and was not observed in the lake water that was incubated under aerobic or light conditions (Fig. 2). Woolson (1977) also reported that, in the soil under aerobic conditions, methylarsenic was not converted to arsenate. Several kinds of organic matter were degraded only under anaerobic environments, including the sediments of lakes, suggesting that the anaerobic microbial population contributes to the degradation (Fathepure and Vogel, 1991; Coates et al., 2001; Bastviken et al., 
2004). Anaerobic microbial reactions in the lake water of Lake Kahokugata would be relatively optimal for converting DMA to inorganic arsenic. In Lake Kahokugata, which averages slightly less than $2 \mathrm{~m}$ in depth, the water would be vertically mixed in all seasons, and the DMA-degrading bacteria would be transported from the lake sediments, which is under dark and anaerobic conditions.

Moreover, under light conditions, phototrophic microorganisms can grow and produce greater amounts of organic matter than under dark conditions and create the dynamics of a microbial population (Takenaka et al., 2007). Organic matter, such as glucose, is known to inhibit the degradation of methylarsenic compounds (Gao \& Burau, 1997). The addition of glucose into the lake water of Lake Kahokugata inhibited the DMA degradation (data not shown). Accordingly, DMA biodegradation under light conditions might be reduced by the products of phototrophic microorganisms. Furthermore, as described, some phototrophic organisms, such as fungi and plankton, are reported to uptake inorganic arsenic and convert it into DMA (Hasegawa et al., 2001; Santosa et al., 1994). However, in this study, the biosynthesis of DMA in the lake water was at relatively low levels under aerobic and light conditions and was not observed under aerobic and dark and anaerobic and light conditions (Fig. 3). Cheng and Focht (1979) also reported that microorganisms involved in the demethylation process in the soil were more abundant than DMA-synthesizing microorganisms. In Lake Kahokugata, DMA synthesis by phytoplankton grown under aerobic and light conditions should also be at low levels but might offset, to some degree, the DMA decrease by biodegradation.

DMA-biodegradation activities are thought to influence the seasonal changes in the concentrations of DMA, which are caused by microorganisms. When lake water collected in all seasons and spiked with $1 \mu \mathrm{M}$ of DMA was incubated at $20^{\circ} \mathrm{C}$, the DMA in most of lake water samples in the four seasons was converted to inorganic arsenic in 21 or $35 \mathrm{~d}$ (Fig. 4). The species compositions of DMA-degrading bacteria have been reported to change seasonally in Lake Kahokugata (Maki et al., 2005). Anderson and Bruland (1991) reported that, in a number of lakes and estuaries, the rates of DMA degradation were faster in water in winter when the water layer was mixed. However, the depth of Lake Kahokugata was shallow at less than $2 \mathrm{~m}$ and the water was constantly mixed throughout the four seasons. Therefore, the DMA-degradation experiments performed under incubation at $20^{\circ} \mathrm{C}$ indicated that similar rates of potential DMA degradation were obtained in all four seasons regardless of the seasonal changes of bacterial composition. On the other hand, the DMA spiked into some samples of lake water in spring, summer, and fall continued to be degraded for incubation times ranging from 35 and $56 \mathrm{~d}$. In some sampling days of spring, summer, and fall, the low abundance of microorganisms transported from the lake sediments may reduce the DMA-degradation activities. Moreover, phytoplankton activities that synthesize DMA and increase from spring to summer (Fig. 1a) are thought to reduce the rate of DMA decrease and inorganic arsenic accumulation in the natural lake water in the spring, summer, and fall.

Furthermore, in the lake water that was collected in the summer and incubated at $30^{\circ} \mathrm{C}, 1 \mu \mathrm{M}$ of DMA was rapidly degraded at incubation times ranging from 7 to $21 \mathrm{~d}$ (Fig. 5a). When the lake winter water samples were incubated at $4{ }^{\circ} \mathrm{C}$, DMA degradation was negligible (Fig. $5 \mathrm{~b}$ ). The water temperature in aquatic environments was reported to influence the dynamics of bacterial communities and the levels of metabolic activities by microorganisms (Simon et al., 1999; Pomeroy and Wiebe, 2000). In Lake Kahokugata, the water temperature was below $10^{\circ} \mathrm{C}$ in fall and winter, while it increased to over $30^{\circ} \mathrm{C}$ from spring to summer (Fig. 1b). Although the potential rates of DMA degradation under incubation at $20^{\circ} \mathrm{C}$ maintained similar levels in all seasons (Fig. 4), the water temperature could change the DMA-degradation activities in the lake water and overcome the potential activities of DMA degradation in each season. The low temperature in winter would reduce the DMA-biodegradation activities, while the high temperature in summer would activate the DMA biodegradation in Lake Kahokugata. Consequently, organoarsenic compounds might maintain a concentration of up to $20 \mathrm{nM}$ in winter, and the high microbial activities in summer might degrade organoarsenic compounds in the lake water.

\section{Conclusions}

This is the first report directly demonstrating that DMA biodegradation in aquatic environments is enhanced under anaerobic and dark conditions. Although the DMA degradation potentially maintained the same rates throughout the four seasons, the seasonal dynamics of the DMA-biodegradation activities in Lake Kahokugata are thought to depend on changes in the water temperature. In Lake Kahokugata, the residue of DMA was detected only during fall and winter, when the low water temperature would reduce the DMA biodegradation. In summer, DMA in the lake is thought to disappear due to the high activities of DMA-biodegradation at high temperatures. Considering the arsenic cycles in aquatic environments, the biodegradation process of organoarsenic compounds appeared to be as important as the biosynthesis process of organoarsenic compounds. In the future, since the arsenic cycles were composed of a highly complex structure of organoarsenic compounds such as arsenobetaine, which are also produced by microorganisms, the processes of degradation and biosynthesis involving highly complex organoarsenic compounds should be investigated in order to elucidate the arsenic cycles in aquatic environments.

\section{Acknowledgements}

This research was supported by a Grant-in-Aid for the Encouragement of Young Scientists (17710061) from the Ministry of Education, Science, Sports and Culture. The Salt Science Research Foundation, No. 0424, and the Nissan Science Foundation also support this work.

\section{References}

Anderson, L.C.D., Bruland, K.W., 1991. Biogeochemistry of arsenic in natural waters: the importance of methylated species. Environ. Sci. Technol. 25, 420-427.

Andreae, M.O., 1979. Arsenic speciation in seawater and interstitial waters: the influence of biological-chemical interactions on the chemistry of a trace element. Limnol. Oceanogr. 24, 440-452.

Bastviken, D., Persson, L., Odham, G., Tranvik, L., 2004. Degradation of dissolved organic matter in oxic and anoxic lake water. Limnol. Oceanogr. 49, 109-116.

Braman, R.S., Foreback, C.C., 1973. Methylated forms of arsenic in the environment Science 182, 1247-1249.

Cheng, C.N., Focht, D.D., 1979. Production of arsine and methylarsines in soil and in culture. Appl. Environ. Microb. 38, 494-498.

Coates, J.D., Chakraborty, R., Lack, J.G., O'Connor, S.M., Cole, K., 2001. Anaerobic benzene oxidation coupled to nitrate reduction in pure culture by two novel organism. Nature 411, 1039-1043.

Cullen, W.R., Reimer, K.J., 1989. Arsenic speciation in the environment. Chem. Rev. 89, 713-764.

Farías, S., Smichowski, P., Vélez, D., Montoro, R., Curtosi, A., Vodopívez, C., 2007. Total and inorganic arsenic in Antarctic macroalgae. Chemosphere 69, 1017 1024.

Fathepure, B.Z., Vogel, T.M., 1991. Complete degradation of polychlorinated hydrocarbons by a two-stage biofilm reactor. Appl. Environ. Microbiol. 57 3418-3422.

Francesconi, K.A., Kuehnelt, D., 2002. Arsenic compounds in the environment. In: Frankenberger, W.T. (Ed.), Environmental Chemistry of Arsenic. Marcel Dekker New York, USA, pp. 51-94.

Gao, S., Burau, R.G., 1997. Environmental factors affecting rates of arsine evolution from and mineralization of arsenicals in soil. J. Environ. Qual. 26, 753-763.

Hasegawa, H., 1996. Seasonal changes in methylarsenic distribution in Tosa Bay and Uranouchi Inlet. Appl. Organomet. Chem. 10, 733-740.

Hasegawa, H., Sohrin, Y., Matsui, M., Honjo, M., Kawashima, M., 1994. Speciation of arsenic in natural waters by solvent extraction and hydride generation atomic absorption spectrometry. Anal. Chem. 66, 3247-3252. 
Hasegawa, H., Sohrin, Y., Seki, K., Sato, M., Norisuye, K., Naito, K., Matsui, M., 2001. Biosynthesis and release of methylarsenic compounds during the growth of freshwater algae. Chemosphere 43, 265-272.

Jenkins, R.O., Ritchie, A.W., Edmonds, J.S., Goessler, W., Molenat, N., Kuehnelt, D. Harrington, C.F., Sutton, P.G., 2003. Bacterial degradation of arsenobetaine via dimethylarsinoylacetate. Arch. Microbiol. 180, 142-150.

Kaise, T., Hanaoka, K., Tagawa, S., 1985. The formation of trimethylarsine oxide from arsenobetaine by biodegradation with marine microorganisms. Chemosphere $16,2551-2558$.

Khokiattiwong, S., Goessler, W., Pedersen, S.N., Cox, R., Francesconi, K.A., 2001 Dimethylarsinoylacetate from microbial demethylation of arsenobetaine in seawater. Appl. Organomet. Chem. 15, 481-489.

Lehr, C.R., Polishchuk, E., Radoja, U., Cullen, W.R., 2003. Demethylation of methylarsenic species by Mycobacterium neoaurum. Appl. Organomet. Chem. $17,831-834$

Maki, T., Hasegawa, H., Ueda, K., 2005. Seasonal dynamics of dimethylarsinic acid (DMAA) decomposing bacteria dominated in Lake Kahokugata. Appl. Organomet. Chem. 19, 231-238.

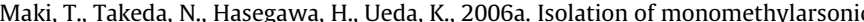
acid (MMAA)-mineralizing bacteria from arsenic contaminated soils of Island Ohkunoshima. Appl. Organomet. Chem. 20, 538-544.

Maki, T., Watarai, H., Kakimoto, T., Takahashi, M., Hasegawa, H., Ueda, K., 2006b. Seasonal dynamics of dimethylarsenic acid degrading bacteria dominated in Lake Kibagata. Geomicrobiol. J. 23, 311-318.

Ninh, T.D., Nagashima, Y., Shiomi, K., 2008. Unusual arsenic speciation in sea anemones. Chemosphere 70, 1168-1174.
Oremland, R.S., Stolz, J.F., 2003. The ecology of arsenic. Science 300, 939-944.

Peshut, P.J., Morrison, R.J., Brooks, B.A., 2008. Arsenic speciation in marine fish and shellfish from American Samoa. Chemosphere 71, 484-492.

Pomeroy, L.R., Wiebe, W.J., 2000. Temperature and substrates as interactive limiting factors for marine heterotrophic bacteria. Aquat. Microb. Ecol. 23, 187-204.

Quinn, J.P., McMullan, G., 1995. Carbon-arsenic bond cleavage by a newly isolated gram-negative bacterium, strain ASV2. Microbiology 141, 721-725.

Sanders, J.G., 1979. Microbial role in the demethylation and oxidation of methylated arsenicals in seawater. Chemosphere 8, 135-137.

Santosa, S.J., Wada, S., Tanaka, S., 1994. Distribution and cycle of arsenic compounds in the ocean. Appl. Organomet. Chem. 8, 273-283.

Simon, M. Glöckner, F.O. Amann, R. 1999. Different community structure and temperature optima of heterotrophic picoplankton in various regions of the Southern Ocean. Aquat. Microb. Ecol. 18, 275-284.

Sohrin, Y., Matsui, M., Kawashima, M., Honjo, M., Hasegawa, H., 1997. Arsenic biogeochemistry affected by eutrophication in lake Biwa. Jpn. Environ. Sci. Technol. 31, 2712-2720.

Stolz, J.F., Basu, P., Santini, J.M., Oremland, R.S., 2006. Arsenic and selenium in microbial metabolism. Annu. Rev. Microbiol. 60, 107-130.

Takenaka, T., Tashiro, T., Ozaki, A., Takakubo, H., Yamamoto, Y., Maruyama, T., Nagaosa, K., Kimura, H., Kato, K., 2007. Planktonic bacterial population dynamics with environmental changes in coastal areas of Suruga Bay. Microbes Environ. 22, 257-267.

Woolson, E.A., 1977. Generation of alkylarsines from soil. Weed Sci. 25, 412-416. 